\title{
Erratum to: Microbiological attributes and biogenic amine content of probiotic Turkish fermented sausage
}

\author{
Bülent Ergönül • Akif Kundakçı
}

Published online: 16 December 2010

(C) Springer Basel AG 2010

\section{Erratum to: J Verbr Lebensm}

DOI 10.1007/s00003-010-0584-0

Unfortunately, Table 1 has not been published in the text and the missing table is given here;

The heading "Table 1. Microbiological attributes of fermented sausage samples" is corrected as "Table 2 . Microbiological attributes of fermented sausage samples" and the heading "Table 2 . Biogenic amine contents of fermented sausage samples" is corrected as "Table 3. Biogenic amine contents of fermented sausage samples".

Table 1 Fermentation and drying program including temperature and relative humidity values

\begin{tabular}{lll}
\hline Relative humidity $(\%)$ & Temperature $\left({ }^{\circ} \mathrm{C}\right)$ & Period $(\mathrm{h})$ \\
\hline $93 \pm 1$ & $24 \pm 1$ & 24 \\
$93 \pm 1$ & $22 \pm 1$ & 24 \\
$88 \pm 1$ & $20 \pm 1$ & 24 \\
$85 \pm 1$ & $18 \pm 1$ & 24 \\
$80 \pm 1$ & $18 \pm 1$ & 24 \\
$78 \pm 1$ & $17 \pm 1$ & 24 \\
$77 \pm 1$ & $17 \pm 1$ & 48 \\
\hline
\end{tabular}

The online version of the original article can be found under doi:10.1007/s00003-010-0584-0.

Dr. B. Ergönül $(\varangle) \cdot$ A. Kundakçı

Engineering Faculty, Food Engineering Department,

Celal Bayar University, Muradiye Campus,

Muradiye, Manisa, Turkey

e-mail: bulent.ergonul@bayar.edu.tr
In Results and Discussion part, in the 10th and 12th paragraphs, the term "Table 1" is corrected as "Table 2"; whereas the term "Table 2" is corrected as "Table 3" in 1st, 8th, 10th and 14th paragraphs in section "Changes in biogenic amine contents of probiotic sausage". Putrescine contents of the samples were changing between 1.98 and 35.48 ppm just after manufacturing and at the end of the refrigerated storage respectively, whereas these values were 0.96-18.50 ppm for cadaverine, 1.41-10.84 ppm for histamine and 1.75-9.36 ppm for tyramine. 